\title{
Influencing factors on career choice and current occupation analysis of adult survivors of childhood cancer: a special focus on health-related occupations
}

\author{
Istvan-Szilard Szilagy · Eva Nagele • Christine Fürschuß · Andrea Mohapp · Karin Wiegele · Herwig Lackner • \\ Christian Urban
}

Received: 27 November 2018 / Accepted: 30 January 2019 / Published online: 18 February 2019

(C) The Author(s) 2019

\begin{abstract}
Summary
Background Planning a career and choosing a profession is an important step in the future development to adolescence. Although cancer and the consequences of the disease have a high impact on the bio-psychosocial level, less is known concerning the profession prevalence of childhood cancer survivors. Therefore, major influencing factors on career choice and current occupations of former Austrian childhood cancer patients have been analysed, especially focusing on health-related occupations.

Methods A survey battery including possible influencing factors on career choice was sent by mail. Physical and daily life impairment was evaluated by the quality of life survey (SF-12) and an adapted version of the Pain Disability Index (PDI). In total, 102 survivors with a mean age of 32.8 (SD 4.9) years (50\% women) participated.

Results A significantly high proportion of survivors was found currently holding health-related occupations, also when compared to the general Austrian population. Disease and treatment, female gender, social and family circumstances have substantial im-
\end{abstract}

I.-S. Szilagy and E. Nagele contributed equally to this work.

I.-S. Szilagy · E. Nagele $(\bowtie) \cdot$ C. Fürschuß · A. Mohapp ·

K. Wiegele $\cdot$ H. Lackner $\cdot$ C. Urban

Division of Paediatric Haemato-Oncology, Medical

University of Graz, Auenbruggerplatz 34/2, 8036 Graz,

Austria

eva.nagele@medunigraz.at

I.-S. Szilagy

Department of Paediatrics and Adolescent Surgery, Medical University of Graz, Graz, Austria

\section{E. Nagele}

Department of Internal Medicine, Division of Haematology, Medical University of Graz, Auenbruggerplatz 38, 8036 Graz, Austria pact on the choice of a health-related career. Mean SF-12 scores were comparable to a healthy reference group, although scores for mental health were marginally lower in our group, and scores for physical health were slightly higher. The PDI scores were very low, which indicates no major influences in everyday activities.

Conclusions There was found a significant trend that adult survivors of childhood cancer are more likely to work in health-related professions than the average population. Occupational planning should consequently be supported and mental health might be addressed during regular follow-up visits.

Keywords Oncology · Haematology · Distress · Survivorship · Quality of life

\section{Introduction}

Cancer diagnosis in childhood and adolescence has a substantial impact on a young person's life. Cancer and its treatment can cause various undesirable physical effects such as pain, organ destruction and even physical disability. Additionally, cancer illness can lead to post-traumatic stress disease, anxiety, depression, existential concerns, identity crisis and fear of cancer recurrence [1-6]. The impaired reproductive health of childhood cancer survivors importantly influences the life and global decision making $[7,8]$. As a result of improvements in treatment, 3 of 4 children with cancer recover [9-12]. Through advances in cancer treatment, psychological and social support, the quality of life of childhood cancer patients or childhood cancer survivors has improved significantly [13-16]. But for most of these young people professionally based educational and employment counselling, considering their physical and psychological condition and needs, is still lacking. Especially with 
the onset of adulthood, different areas of life planning such as occupational decisions become essential for a childhood cancer patient [5, 17-19].

Different theories and concepts have been developed over the years with regard to general influences on young people's career choices. Certain theories assume that a person's self-image is the main predictor of one's profession. Other theories take Maslow's hierarchy of needs as the foundation of decisionmaking [20]. Occupational choice may be difficult if there is a lack of information about one's own personal resources and about possible occupations of careers [21]. The disease and the consequences of the disease have fundamentally significant impacts on a bio-psycho-social level, on the future of young people and their steps towards planning a career and choosing a profession.

To achieve financial independence, social integration and self-efficacy, career choice is an essential step in a young person's journey to adulthood [19]. In addition to the biological realities of cancer and cancer treatment (such as: pain, fatigue, changes in physical appearance) in the development to adolescence, social and every-day related factors play a significant role such as disease management or doctor-patient interaction. Affected children and young people in the course of their development to adolescence have fears of the future. They wish to be healthy and normal, to continue friendships, to find new friends, to be socially accepted by peers, to acquire autonomy and independence as well as a good education and the pursuit of a profession [13, 22-24]. Currently existing studies deal mainly with former oncology patients who already have career experience and aim to return to the working world. In those studies, the main criteria that were identified to influence a person's return to work were cancer type [25], reactions to treatment or society, influences due to productivity factors [26], graduation, frequency of sick leave [2], gender and age $[1,6]$. A latest study focused on the interaction of treatment-, health-, and vocational-related factors and career development among childhood cancer survivors. The authors concluded that addressing career readiness may be important to improve employment outcomes for adult survivors of childhood cancer [19].

With the following study current professions and major factors that have an influence on the career choice of childhood cancer survivors will be examined with a special focus on health-related professions.

\section{Materials and methods}

\section{Subjects}

All paediatric oncology patients who were formerly treated at the Division of Paediatric Haemato-Oncology, Medical University of Graz in Austria, and fulfilled the inclusion criteria, were selected. Selection criteria were age ranging from 25 to 45 years, former haematological or oncological cancer and voluntary participation. Based on the assumption that persons between 25 and 45 years already would have made a career choice, former patients within this age were selected from the database.

\section{Measures}

Factors that influence physiological and psychosocial life or have an impact on career choice and two validated questionnaires, the Short Form 12 Health Survey Questionnaire (SF-12) [27, 28] and the Pain Disability Index (PDI) [29], were included in the survey battery which was constructed by experienced clinical psychologists. Demographic details and treatment-related questions were also covered.

Influencing factors on the career choice were compiled using various items identified after reviewing the literature. In total, 18 factors influencing the career choice in general were identified and should be then assessed by the participants on a five-point scale from 1 , absolutely no influence, to 5 , very significant influence: self-dependence, prestige, illness experience, personal interests, personal skills, education, social expectations, media, advertising, economic/ financial interests, societal benefits, cooperation with other groups, communication, workplace security, life satisfaction through work, function as role model, family experience with the disease and loss of a family member [20, 30-32].

The Short Form 12 Health Survey Questionnaire (SF12) is a disease cross-measuring instrument to assess patients' health-related quality of life. Eight domains of subjective health (physical functioning, physical role function, pain, general health perception, vitality, social functioning and emotional role function) are summarised in two dimensions-the physical and mental summary scales. The scores can be rated from 0 to 100 . The higher the scores, the higher is the quality of life. The questionnaire is optimal for efficient screening of patients' health-related quality of life [27, 28].

The Pain Disability Index (PDI) included an adjusted instruction for childhood cancer survivors and was used focusing on the influence of cancer illness and treatment on essential life activities. The PDI focuses on factors that can impair everyday activities, such as family/home, recreation, social activities, occupation, sexual behaviour, self-care, and life-support activities. Partnership was added as another item. A rating scale from 0 to 10 was used. The higher the overall score, the higher is the disability (0-80) [29].

The survey battery was sent out between 12/2012 and 06/2013 in collaboration with the Division of Paediatric Haematology and Oncology database team and comprised an information letter, two declarations of consent and a prepared return envelope with the address of the Division. Participants were asked to com- 
plete and return the survey within two weeks. We used the STROBE checklist in order to carry out a high standard study [33]. The study was approved by the Ethics Committee of the Medical University of Graz (EK-Nr.: 25-061 ex 12/13).

\section{Statistics}

Descriptive analyses were performed to evaluate the demographic data. To determine whether an association in the sample distribution occurred randomly or systematically, as well as the possible strength of an association, we used contingency tables and calculated chi-squares or Fisher's exact tests. Standardised residuals were used to evaluate the differences between observed and expected values and to determine whether a small or large deviation is given. The evaluation of the differences between ordinal variables was conducted using nonparametric u-tests as well as NPAR test.

As our hypothesis that many childhood cancer survivors choose to work in health-related fields was based on many years of work experience of our multidisciplinary team, we designated occupation type as the dependent variable (health-related career $v s$. nonhealth-related career). So we further analysed whether former cancer patients decide to choose health-related careers disproportionally more frequent and which factors influence health-related careers. The independent variables were demographic data with interval and nominal scaling dimensions, nominally scaled treatment-related variables, variables encompassing the influence on career choice and quality of life-related variables. The survey battery contained single question items with five or ten levelled rating scales, as well as multiple-choice items. Depending on the hypotheses we have dichotomized the rating scales for single items. To capture satisfaction and impairment-related data, we also implemented selfassessment items. To evaluate which factors influence the probability of working in health-related professions, we used a logistic regression and compared the dependent variable "current health-related" vs. "nonhealth-related profession" with different variables that we identified in the literature that may have an impact on career choice. To compare the career distribution of the Austrian population in 2012 to our chosen study population, we additionally obtained statistical data from Statistics Austria, an independent and nonprofit-making federal institution under public law. Categories for current professions are based on groupings of the Austrian Public Employment Service. Statistical analysis was performed using IBMSPSS Statistics Professional 19 and Microsoft Excel 2010.
Table 1 Demographic data

\begin{tabular}{|c|c|c|c|}
\hline Demographic data & Total (102) & $\begin{array}{l}\text { Women } \\
\text { (51) }\end{array}$ & Men (51) \\
\hline Age. mean (SD) & $32.8(4.9)$ & $33.5(5.2)$ & $32.2(4.6)$ \\
\hline \multicolumn{4}{|l|}{ Civil Status (\%) } \\
\hline Single (\%) & 52 & 56.9 & 47.1 \\
\hline Civil union (\%) & 22.5 & 27.5 & 17.6 \\
\hline Married (\%) & 22.5 & 9.8 & 35.3 \\
\hline Divorced (\%) & 2 & 3.9 & - \\
\hline Widowed (\%) & 1 & 2 & - \\
\hline \multicolumn{4}{|l|}{ Social bound (residing) (\%) } \\
\hline Alone (\%) & 24.5 & 34.7 & 14.3 \\
\hline With partner (\%) & 61.2 & 55.1 & 67.3 \\
\hline With parents (\%) & 14.3 & 10.2 & 18.4 \\
\hline Children (\%) & 36.3 & 41.2 & 31.4 \\
\hline \multicolumn{4}{|l|}{ Education (\%) } \\
\hline Mandatory school (\%) & 4.9 & 9.8 & - \\
\hline Apprenticeship (\%) & 29.4 & 19.6 & 39.2 \\
\hline Vocational school (\%) & 12.7 & 9.8 & 15.7 \\
\hline General secondary school (\%) & 6.9 & 9.8 & 3.9 \\
\hline Vocational high school (\%) & 12.7 & 13.7 & 11.8 \\
\hline Kolleg (\%) & 2 & 3.9 & - \\
\hline College (\%) & 6.9 & 9.8 & 3.9 \\
\hline University (\%) & 24.5 & 23.5 & 25.5 \\
\hline \multicolumn{4}{|l|}{ Cancer type ${ }^{\mathrm{a}} n(\%)$} \\
\hline $\begin{array}{l}\text { Acute lymphoblastic leukaemia } \\
n(\%)\end{array}$ & $22(26.8)$ & $11(28.2)$ & $11(25.6)$ \\
\hline Acute myeloid leukaemia $n(\%)$ & $5(6.1)$ & $1(2.6)$ & $4(9.3)$ \\
\hline $\begin{array}{l}\text { Chronic myelogenous } \\
\text { leukaemia } n(\%)\end{array}$ & $1(1.2)$ & $1(2.6)$ & - \\
\hline Non-Hodgkin lymphoma $n(\%)$ & $10(12.2)$ & $3(7.7)$ & $7(16.3)$ \\
\hline Hodgkin lymphoma $n(\%)$ & $11(13.4)$ & $6(15.4)$ & $5(11.6)$ \\
\hline Low grade glioma $n(\%)$ & $1(1.2)$ & - & $1(2.3)$ \\
\hline Medulloblastoma $n(\%)$ & $1(1.2)$ & - & $1(2.3)$ \\
\hline Ependymoma $n(\%)$ & $1(1.2)$ & - & $1(2.3)$ \\
\hline Craniopharyngioma $n(\%)$ & $2(2.4)$ & $1(2.6)$ & $1(2.3)$ \\
\hline Neuroblastoma $n(\%)$ & $4(4.9)$ & - & $4(9.3)$ \\
\hline Wilms' tumor $n(\%)$ & $4(4.9)$ & $3(7.7)$ & $1(2.3)$ \\
\hline Ewing's sarcoma $n(\%)$ & $6(7.3)$ & $3(7.7)$ & $3(7.0)$ \\
\hline Osteosarcoma $n(\%)$ & 7 (8.5) & $5(12.8)$ & $2(4.7)$ \\
\hline Soft-tissue sarcoma $n(\%)$ & $3(3.7)$ & $2(5.1)$ & $1(2.3)$ \\
\hline Germ cell tumour $n(\%)$ & $2(2.4)$ & $2(5.1)$ & - \\
\hline Retinoblastoma $n(\%)$ & $1(1.2)$ & - & $1(2.3)$ \\
\hline $\begin{array}{l}\text { Langerhan's cell histiocytosis } n \\
\text { (\%) }\end{array}$ & $1(1.2)$ & $1(2.6)$ & - \\
\hline
\end{tabular}

\section{Results}

\section{Patient characteristics}

In total 440 former patients of the division of paediatric haematology and oncology were contacted by letter. Addresses were retrieved from our medical database, 90 envelopes with postal notes of incorrect addresses or relocation were returned (20.5\%). We 
Table 1 (Continued)

\begin{tabular}{|c|c|c|c|}
\hline Demographic data & Total (102) & $\begin{array}{l}\text { Women } \\
\text { (51) }\end{array}$ & Men (51) \\
\hline \multicolumn{4}{|l|}{ Treatment ${ }^{\mathrm{b}} n(\%)$} \\
\hline Surgery $n(\%)$ & $45(21.5)$ & $24(22.6)$ & $21(20.4)$ \\
\hline Amputation $n(\%)$ & $6(2.9)$ & $3(2.8)$ & $3(2.9)$ \\
\hline Enucleation $n(\%)$ & $10(4.8)$ & $4(3.8)$ & $6(5.8)$ \\
\hline Radiotherapy $n(\%)$ & $54(25.8)$ & $26(24.5)$ & $28(27.2)$ \\
\hline Chemotherapy $n$ (\%) & $85(40.7)$ & $42(39.6)$ & $43(41.7)$ \\
\hline Transplantation $n(\%)$ & $9(4.3)$ & $7(6.6)$ & $2(1.9)$ \\
\hline Age at diagnosis. mean (SD) & $11.2(5.5)$ & $10.7(5.5)$ & $11.7(5.5)$ \\
\hline $\begin{array}{l}\text { Treatment duration in years. } \\
\text { mean (SD) }\end{array}$ & $2.4(3.7)$ & $2.24(3.6)$ & $2.5(3.8)$ \\
\hline $\begin{array}{l}\text { Follow-up duration in years. } \\
\text { mean }(S D)\end{array}$ & $8.57(4.9)$ & $8.81(4.8)$ & $8.3(5.1)$ \\
\hline \multicolumn{4}{|l|}{ Career type ${ }^{\complement} n(\%)$} \\
\hline Social and education $n(\%)$ & $9(9.6)$ & $9(20)$ & - \\
\hline Media, art and culture $n(\%)$ & $4(4.3)$ & - & $4(8.2)$ \\
\hline Office, business and law $n(\%)$ & $20(21.3)$ & $11(24.4)$ & $9(18.4)$ \\
\hline $\begin{array}{l}\text { Construction-related and car- } \\
\text { pentry industries } n(\%)\end{array}$ & $12(12.8)$ & $1(2.2)$ & $11(22.4)$ \\
\hline $\begin{array}{l}\text { Chemicals, plastics. Raw mate- } \\
\text { rials and mining } n(\%)\end{array}$ & $3(3.2)$ & $2(4.4)$ & $1(2)$ \\
\hline Electrical and electronic $n(\%)$ & $5(5.3)$ & $1(2.2)$ & $4(8.2)$ \\
\hline $\begin{array}{l}\text { Gardening, farming and forestry } \\
n(\%)\end{array}$ & $3(3.2)$ & - & $3(6.1)$ \\
\hline Health and medicine $n(\%)$ & $20(21.3)$ & $14(31.1)$ & $6(12.2)$ \\
\hline $\begin{array}{l}\text { Trading, sales and advertising } n \\
(\%)\end{array}$ & $1(1.1)$ & - & $1(2)$ \\
\hline $\begin{array}{l}\text { Helping professions and tempo- } \\
\text { rary staff } n(\%)\end{array}$ & $1(1.1)$ & - & $1(2)$ \\
\hline Hotel and hospitality $n(\%)$ & $2(2.1)$ & $2(4.4)$ & - \\
\hline Information technology $n(\%)$ & $1(1.1)$ & - & $1(2)$ \\
\hline Body and beauty care $n(\%)$ & $2(2.1)$ & $2(4.4)$ & - \\
\hline $\begin{array}{l}\text { Machinery, automobile and } \\
\text { metal } n(\%)\end{array}$ & $7(7.4)$ & - & $7(14.3)$ \\
\hline Cleaning and household $n(\%)$ & $1(1.1)$ & $1(2.2)$ & - \\
\hline $\begin{array}{l}\text { Textile, clothing and leather } n \\
(\%)\end{array}$ & $1(1.1)$ & $1(2.2)$ & - \\
\hline $\begin{array}{l}\text { Traffic, transport and delivery } n \\
(\%)\end{array}$ & $1(1.1)$ & $1(2.2)$ & - \\
\hline $\begin{array}{l}\text { Science, research and develop- } \\
\text { ment } n(\%)\end{array}$ & $1(1.1)$ & - & $1(2)$ \\
\hline \multicolumn{4}{|c|}{$\begin{array}{l}\text { aData refer to } 82 \text { participants. For } 20 \text { former patients, insufficient informa- } \\
\text { tion was available or data were missing } \\
\text { bultiple answers were possible } \\
\text { 'Data refer to } 94 \text { participants. For } 8 \text { former patients, insufficient information } \\
\text { was available or data were missing } \\
S D \text { standard deviation }\end{array}$} \\
\hline
\end{tabular}

also received the information that two former patients had died. From the remaining 348 patients, 103 individuals participated in our study (30\%). One record was not analysable. Considering the participants who could not be reached as well as the deceased, we obtained a return rate of $23 \%$. Exactly 51 of the participants were male and 51 female. The average age of participants was 32.8 years (standard deviation [SD] 4.9). Apprenticeship was highly represented as education level (29.4\%), followed by university degree $(24.5 \%)$. About half of the group had a partner. The most common type of cancer among the responders was acute lymphoblastic leukemia (26.8\%) followed by Hodgkin lymphoma (13.4\%) and non-Hodgkin lymphoma (12.2\%). Mean age at diagnosis was 11 years (SD 5.5) and the mean duration of treatment was 2.4 years (SD 3.7) with a followup duration of 8.6 years (SD 4.9) (see Table 1). In total, $85 \%$ of the responders were highly satisfied with the therapeutic success. We did not find any significant differences related to gender and cancer type between the responders and nonresponders, only age-related differences, where responders showed a slightly higher age median (median 32; 25th/75th percentiles: 29/35.50) than did nonresponders (median: 31 ; 25th/75th percentiles 25/75: 28/35).

\section{Influencing factors on career choices and current occupation analysis}

Cancer illness and therapy were reported as important influencing factors on the career choice of adult survivors of childhood cancer, disproportionally more often by women $\left(\mathrm{Chi}^{2}=5.929, p<0.05\right)$ and participants who were living alone or together with their parents $\left(\mathrm{Chi}^{2}=7.958, p<0.05\right)$ or by former patients with osteosarcomas (median $=10$; percentile 25/75 $=4.75 / 10$ ). Former patients who assessed their illness as very or extremely important during their lives $\left(\mathrm{Chi}^{2}=37.531\right.$, $p<0.001$ ) or had family members with important illness experiences also reported significantly more often to be influenced in their career choice by cancer illness and therapy $\left(\mathrm{Chi}^{2}=10.782, p<0.05\right)$.

The statistical analysis demonstrates that participants who felt affected in their career choice by cancer illness and therapy were disproportionally more frequently working in health-related professions or in social fields and in education or body and beauty care professions $\left(\mathrm{Chi}^{2}=30.545, p<0.05\right)$.

The occupational plan of childhood cancer survivors had a significant coherence with the current occupation. Disproportionally more frequent former patients who intended to work in a health-related occupation worked in health-related fields $(p<0.01)$. Furthermore a relationship was found between occupation plans of childhood cancer survivors and the actual occupation of their mothers, e.g. those patients whose mothers worked in health-related fields also planned to work in health-related professions.

Based on the logistic regression analysis, childhood cancer survivors currently working in healthrelated professions mentioned their own experience with the illness $(p<0.05 ; \mathrm{df}=1)$, occupational plan $(p<0.05 ; \mathrm{df}=1)$ and illness experience of family members $(p<0.05 ; \mathrm{df}=1)$ as factors with significantly high impact on their occupational choice. A career that gives life a sense and independence were also important factors. For participants that have chosen other 
Table 2 Factors that influence the probability of nonhealth-related vs. health-related career

\begin{tabular}{|c|c|c|c|c|c|c|c|c|}
\hline \multirow[t]{2}{*}{ Category } & \multirow{2}{*}{$\begin{array}{l}\text { Regression } \\
\text { coefficient }\end{array}$} & \multirow[t]{2}{*}{ S.e. } & \multirow[t]{2}{*}{ Wald test } & \multirow[t]{2}{*}{ Df } & \multirow[t]{2}{*}{ Sig } & \multirow[t]{2}{*}{$\operatorname{Exp}(b)$} & \multicolumn{2}{|c|}{$95 \% \mathrm{Cl}$ for $\operatorname{Exp}(\mathrm{b})$} \\
\hline & & & & & & & Lower & Upper \\
\hline Sex ${ }^{a}$ & 3.828 & 1.96 & 3.814 & 1 & 0.051 & 45.987 & 0.986 & 2144.242 \\
\hline Independence ${ }^{\mathrm{b}}$ & -1.723 & 0.915 & 3.547 & 1 & 0.06 & 0.178 & 0.03 & 1.073 \\
\hline Prestige $^{b}$ & -0.535 & 0.365 & 2.146 & 1 & 0.143 & 0.586 & 0.286 & 1.198 \\
\hline Own experience with the illness ${ }^{b}$ & -1.71 & 0.872 & 3.848 & 1 & 0.05 & 0.181 & 0.033 & 0.999 \\
\hline Personal interests ${ }^{b}$ & 0.713 & 0.861 & 0.686 & 1 & 0.408 & 2.041 & 0.377 & 11.039 \\
\hline Personal skills ${ }^{b}$ & 0.447 & 1.18 & 0.143 & 1 & 0.705 & 1.563 & 0.155 & 15.791 \\
\hline School $^{b}$ & -0.026 & 0.509 & 0.003 & 1 & 0.959 & 0.974 & 0.359 & 2.642 \\
\hline Social expectancy ${ }^{b}$ & -1.185 & 0.686 & 2.983 & 1 & 0.084 & 0.306 & 0.08 & 1.173 \\
\hline Media $^{b}$ & 0.633 & 0.85 & 0.555 & 1 & 0.456 & 1.883 & 0.356 & 9.959 \\
\hline Advertisment $^{b}$ & 1.788 & 1.483 & 1.455 & 1 & 0.228 & 5.979 & 0.327 & 109.284 \\
\hline Economic interests $^{b}$ & -0.528 & 0.629 & 0.704 & 1 & 0.401 & 0.59 & 0.172 & 2.025 \\
\hline Social benefit reasons ${ }^{b}$ & 2.276 & 1.102 & 4.262 & 1 & 0.039 & 9.735 & 1.122 & 84.464 \\
\hline Relevance to work with a group ${ }^{b}$ & -0.761 & 0.992 & 0.589 & 1 & 0.443 & 0.467 & 0.067 & 3.265 \\
\hline Communication $^{\mathrm{b}}$ & -0.845 & 0.805 & 1.101 & 1 & 0.294 & 0.43 & 0.089 & 2.082 \\
\hline Secure work place ${ }^{b}$ & 0.85 & 0.674 & 1.592 & 1 & 0.207 & 2.34 & 0.625 & 8.769 \\
\hline Career that gives my life a sense ${ }^{b}$ & -1.615 & 0.981 & 2.712 & 1 & 0.1 & 0.199 & 0.029 & 1.359 \\
\hline Following role models ${ }^{b}$ & -0.029 & 0.77 & 0.001 & 1 & 0.97 & 0.971 & 0.215 & 4.391 \\
\hline Illness experience of family members ${ }^{b}$ & -1.675 & 0.756 & 4.902 & 1 & 0.027 & 0.187 & 0.043 & 0.825 \\
\hline Loss of family members because of an illness ${ }^{b}$ & 1.556 & 0.783 & 3.951 & 1 & 0.047 & 4.741 & 1.022 & 21.995 \\
\hline $\begin{array}{l}\text { Influence on the career choice through cancer illness and } \\
\text { therapy }^{c}\end{array}$ & -2.129 & 1.866 & 1.303 & 1 & 0.254 & 0.119 & 0.003 & 4.607 \\
\hline $\begin{array}{l}\text { Occupational plan (health-related field vs. nonhealth-re- } \\
\text { lated field) }{ }^{c}\end{array}$ & 3.864 & 1.627 & 5.642 & 1 & 0.018 & 47.649 & 1.965 & 1155.287 \\
\hline Constant & -4.552 & 4.238 & 1.154 & 1 & 0.283 & 0.011 & - & - \\
\hline
\end{tabular}

occupational fields, social benefit reasons $(p<0.05$; $\mathrm{df}=1$ ) and loss of family members because of an illness $(p<0.05 ; \mathrm{df}=1)$ were the main influencing factors for their career choice (see Table 2).

The frequency of current professions of the former patients exhibited a high occurrence of healthrelated professions $(21.3 \%)$ as well as careers in office business and law $(21.3 \%)$ followed by constructionrelated and carpentry industries (12.8\%) (see Table 1 and Fig. 1).

The most common health-related profession was nurse with or without diploma $(n=13)$, followed by medical doctor $(n=6)$ and one ergo therapist. Using the career distribution of the Austrian general population from the Statistics Austria as a reference group, we found a significantly higher distribution of participants working in health-related professions in our study population $(p<0.01)$ [34] (see Fig. 2). A significantly higher proportion of female participants have health-related careers than male participants $\left(\mathrm{Chi}^{2}=4.24 ; p<0.05\right)$. No significant differences were found in the following variables in former patients having a health-related career vs. having no health- related career: marital status, social bound, having children, education, cancer type or currently having rehabilitation, age at diagnosis, therapy duration, satisfaction with the treatment result $(p>0.05)$.

The rating scales for two single items (physical and emotional impairment due to their illness) were dichotomized and compared in contingency tables with the Chi-square or Fisher's exact test. A significant difference was identified between former patients holding a health-related career and those former patients that have chosen other occupational fields ("Have you experienced your illness as mentally stressful?"): Former patients holding a health-related career have experienced their illness less stressful compared to former patients working in other occupational fields (Fisher's exact Z-test $=0.024$ ). For the physical impairment which was covered by the question "Have you experienced your illness as physically burdensome?", no significant difference was found between the two groups ( $p>0.05)$. 
Fig. 1 Frequency of current professions among childhood cancer survivors

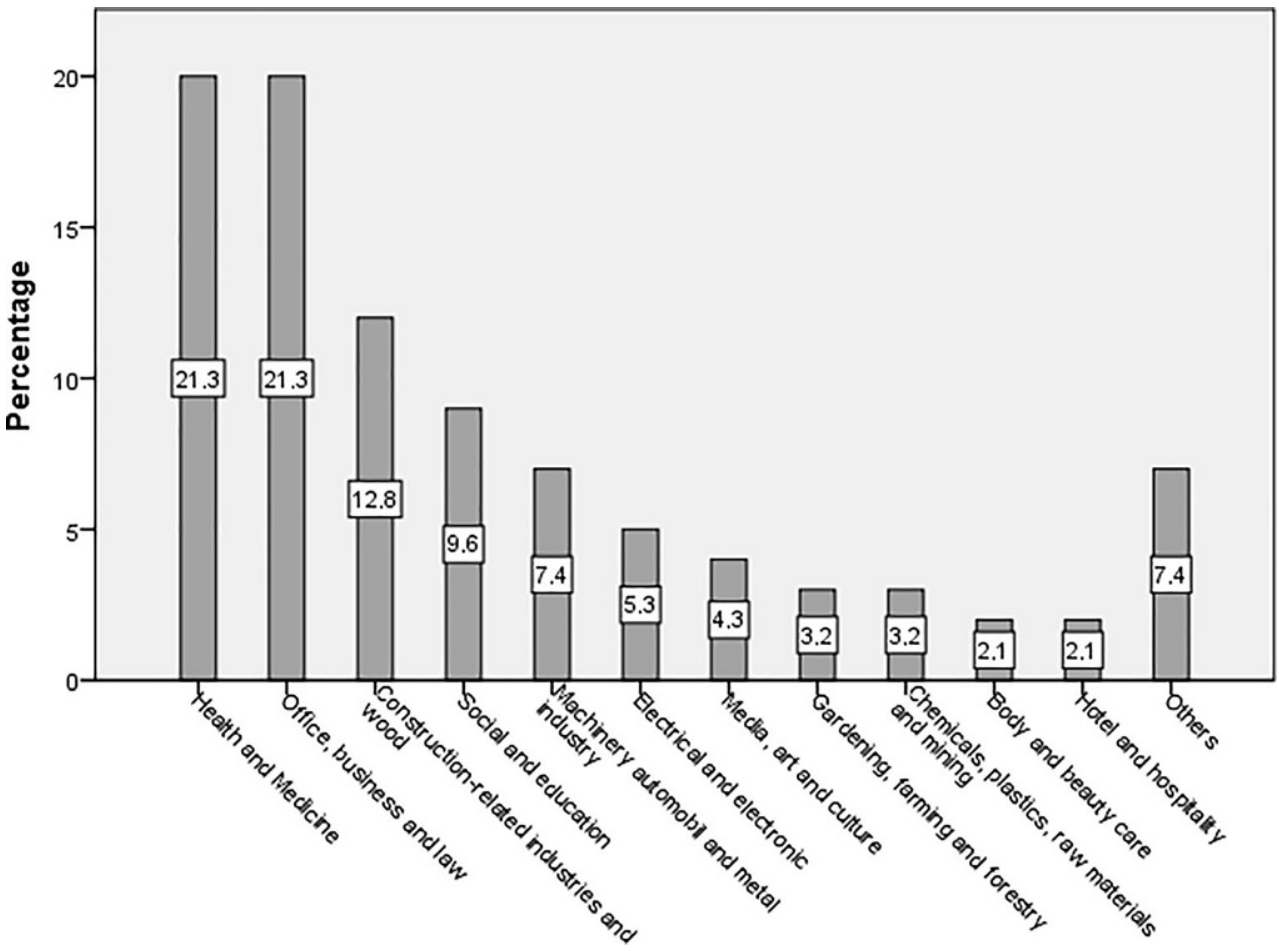

No health-related occupations

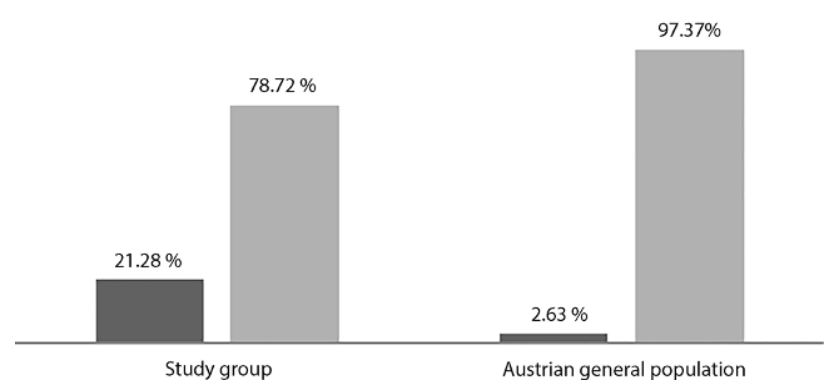

Fig. 2 Frequency of current professions among childhood cancer survivors compared to the Austrian general population from the Statistics Austria

\section{Physical and daily life impairment}

Health-related quality of life in adult survivors of childhood cancer was comparable to the results of a healthy German reference group [27]: While in our study group the SF-12 mean score for physical health was about 3.5 points higher than the mean for the healthy group (mean $=52.5$ [SD $=6.2]$ vs. mean $=49.0[\mathrm{SD}=9.4]$ ), the SF-12 mental health mean score was 2.5 points lower $($ mean $=49.7$ [SD $=10.3$ ] vs. mean $=52.2$ [SD=8.1]). For those participants who currently work in health-related fields vs. nonhealthrelated fields, the SF-12 quality of life questionnaire did not reveal any (significant) differences.

The mean pain disability index for those former cancer patients who participated in our study was 7.4 (SD 11.6) with a median of 1.5. The impairment in everyday activities can therefore be interpreted as very low, with the exception of a few discordant values. The higher scores can be referred to former patients with osteosarcoma $($ mean $=14.5[\mathrm{SD}=113]$; median $=17.0)$. The evaluation between health-related professions and PDI showed no significant differences between participants who answered not to have a healthrelated profession $(p>0.05 ;$ median $=0$; percentile 25/75: 0/9) versus those who worked currently in a health-related profession (median $=3.5$; percentile $25 / 75=0 / 16.5)$.

\section{Discussion}

To our knowledge, this is the first study examining the influences on career choice of adult survivors of childhood cancer and analysing the distribution of their current occupations, another important survivorship issue.

As a main result we found a significant trend that childhood cancer survivors are more likely to work in health-related occupations than the average population. Because former childhood cancer patients experience diverse stages of cancer diagnosis and treatment, one possible explanation for this disproportionately more frequent decision to work in a health-related career could be information assumptions [31]. Within their treatment processes, patients receive a multitude of information about the workflows of health professionals. They therefore become semi-experts about their own disease and treatments. Furthermore, through their oncological treatment and as a part of a multimodal therapy, childhood cancer patients are also psychosocially supported, whereby they explore more information about themselves. 
Such multimodal oncological therapy may increase reliable information about the illness, treatments, and medical workflows while decreasing unreliable information. These factors can contribute to simplifying later decisions with regard to pursuing a healthrelated career $[20,21,31,35]$.

Our results have also shown a gender difference, where female participants are more likely to choose health-related professions than men. The plan to work in a health-related field was identified as one of the influencing factors on career choice: Study participants who had already had this plan before worked disproportionally more frequent in a health-related field. Adult survivors of childhood cancer who have mothers working in health-related fields were also more likely to plan to work in health-related professions themselves, what can be possibly explained by an effect of role models. Factors that were estimated as most important to follow a health-related career by childhood cancer survivors were independence, own experience with the illness, illness experience of family members and occupational plan. These factors may have encouraged our former patients to work in health-related professions interacting in some way with the experience of the illness, which was perceived as less stressful by those patients currently working in health-related fields.

Another interesting result refers to health-related quality of life in our study population. Compared to a healthy reference group [27], the SF-12 mean mental health scores including vitality, social functioning and emotional role were marginally lower in our study group, whereas the physical health mean scores were slightly higher. Former patients also mentioned not to be impaired in everyday activities measured by the PDI. Taking into account the standard deviations, these results need to be interpreted with caution. In a current study also for a majority of former patients with acute lymphoblastic leukaemia an overall good quality of life and physical function was reported [36]. However, this data supported the fact that the mental health of cancer patients should be addressed, next to the physical health, not only during active treatment but also throughout the continuation of followup care [37-39].

In our study we developed a survey battery with partially standardised and partially self-developed questionnaires and performed the interviews by mail. Although the response rate was low, sample size was representative and not too small; numbers of cancer type and gender were well-balanced. Except for age, no significant differences related to gender and cancer type between the responders and nonresponders were found. Our study was limited due to the comparison with the reference group because we could neither extract our population of former cancer patients from the general statistical data of current occupations of the Austrian population, nor the nonresponders' current occupational situation. Responders might represent a subpopulation of survivors with a more positive reference to health-related professions compared to the much bigger group of nonresponders. We have also focused on psychological outcomes and did not systematically cover regular late effects of our participants. Different patient-reported symptoms might be associated with the results on mental and physical health in general. Despite these limitations, our study revealed a higher rate of former childhood cancer patients with health-related professions. Main influencing factors of selecting health-related careers vs. nonhealth-related professions were also shown.

The general influencing factors on career choice give interesting insights for developing further treatment strategies, especially for the psycho-oncological setting. Some patients who are still in rehabilitation, only slowly gain a sense of normality and reintegration into the social structure. School, further education, and career choices become of the highest importance, in order to achieve a normal everyday-life. Adult survivors of childhood cancer should be reintegrated in their daily life activities as effectively as possible. Continuing psychological counselling specifically considering the individual needs of former patients when they are returning to work can be an appropriate measure. Psychosocial rehabilitation measures and rehabilitation projects can support former patients by education and integration, or reintegration, into the social context [40]. It would be of great interest to include regular late effects in the future psychological research. Effective psychosocial support for patients and their families during and after their treatment, in addition to medical therapy, considering their possible late effects is strongly recommended.

Acknowledgements We would like to thank all the former patients who very kindly participated in our study.

Funding This study was funded by the Styrian Childhood Cancer Organisation.

Funding Open access funding provided by Medical University of Graz.

Conflict of interest I.-S. Szilagy, E. Nagele, C. Fürschuß, A. Mohapp, K. Wiegele, H. Lackner and C. Urban declare that they have no competing interests. C. Fürschuß, A. Mohapp, $\mathrm{K}$. Wiegele and H. Lackner are employees of the Division of Paediatric Haemato-Oncology. C. Urban was head of the Division of Paediatric Haemato-Oncology. E. Nagele and I.-S. Szilagy were employees of the Division of Paediatric Haemato-Oncology and are now employees of the Department of Haematology (E. Nagele) respectively the Department of Paediatrics and Adolescent Surgery (I.-S. Szilagy).

Open Access This article is distributed under the terms of the Creative Commons Attribution 4.0 International License (http://creativecommons.org/licenses/by/4.0/), which permits unrestricted use, distribution, and reproduction in any medium, provided you give appropriate credit to the original author(s) and the source, provide a link to the Creative Commons license, and indicate if changes were made. 
Publisher's Note Springer Nature remains neutral with regard to jurisdictional claims in published maps and institutional affiliations.

\section{References}

1. Green DM, Zevon MA, Hall B. Achievement of life goals by adult survivors of modern treatment for childhood cancer. Cancer. 1991;67(1):206-13.

2. Punyko JA, et al. Physical impairment and social adaptation in adult survivors of childhood and adolescent rhabdomyosarcoma: A report from the Childhood Cancer Survivors Study. Psychooncology. 2007;16(1):26-37.

3. Mattsson E, et al. Positive and negative consequences with regard to cancer during adolescence. Experiences two years after diagnosis. Psychooncology. 2007;16(11):1003-9.

4. Meeske KA, et al. Posttraumatic stress, quality of life, and psychological distressinyoung adultsurvivors of childhood cancer. Oncol Nurs Forum. 2001;28(3):481-9.

5. Zebrack BJ, et al. Psychological distress in long-term survivors of solid tumors diagnosed in childhood: A report from the childhood cancer survivor study. Pediatr Blood Cancer. 2007;49(1):47-51. https://doi.org/10.1002/pbc. 20914

6. Zeltzer LK, et al. Psychosocial outcomes and healthrelated quality of life in adult childhood cancer survivors: A report from the childhood cancer survivor study. Cancer Epidemiol Biomarkers Prev. 2008;17(2):435-46.

7. Murphy D, et al. The importance of assessing priorities of reproductivehealth concerns amongadolescentandyoung adult patients with cancer. Cancer. 2015;121(15):2529-36.

8. Shliakhtsitsava K, et al. Best practices in counseling young female cancer survivors on reproductive health. Semin Reprod Med. 2017;35(4):378-89.

9. Gatta G, et al. Childhood cancer survival in Europe and the United States. Cancer. 2002;95(8):1767-72.

10. Gatta G, et al. Childhood cancer survival in Europe. Ann Oncol. 2003;14(Suppl5):v119-v27.

11. Miller RW, Young JL Jr., Novakovic B. Childhood cancer. Cancer. 1995;75(1 Suppl):395-405.

12. Rossig C, et al. Effective childhood cancer treatment: The impact of large scale clinical trials in Germany and Austria. Pediatr Blood Cancer. 2013;60(10):1574-81.

13. Dorfmüller M, editor. Psychoonkologie: Diagnostik-Methoden-Therapieverfahren. München, Jena: Urban \&Fischer; 2008. ISBN 978-3437244902.

14. Armenian SH, Kremer LC, Sklar C. Approaches to reduce the long-term burden of treatment-related complications in survivors of childhood cancer. Am Soc Clin Oncol Educ Book. 2015;35:196-204. https://doi.org/10.14694/ edbook_am.2015.35.196.

15. Li HC, et al. The impact of cancer on the physical, psychological and social well-being of childhood cancer survivors. Eur J Oncol Nurs. 2013;17(2):214-9.

16. Nunez SB, et al. Risk-based health monitoring of childhood cancer survivors: A report from the Children's Oncology Group. Curr Oncol Rep. 2007;9(6):440-52.

17. Gerhardt CA, et al. Educational and occupational outcomes among survivors of childhood cancer during the transition to emerging adulthood. J Dev Behav Pediatr. 2007;28(6):448-55.

18. Haupt R, et al. Educational attainment in long-term survivors of childhood acute lymphoblastic leukemia. JAMA. 1994;272(18):1427-32.
19. Strauser D, et al. Career readiness in adult survivors of childhood cancer: A report from the St. Jude Lifetime CohortStudy. JCancer Surviv. 2015;9(1):20-9.

20. Brown D. Career choice and development. 4th ed. The Jossey-Bass business \& management series. Hoboken: John Wiley \& Sons; 2002.

21. Gati I, Krausz M, OsipowSH.Ataxonomy of difficulties in career decision making. JCouns Psychol. 1996;43(4):510-26.

22. Holling $\mathrm{H}$, et al. Personal, familial and social resources and health-related quality of life in children and adolescents with chronic conditions. Bundesgesundheitsblatt Gesundheitsforschung Gesundheitsschutz. 2008;51(6):606-20.

23. Pinquart M. Wenn Kinder und Jugendlichekörperlich chronisch krank sind. Psychische und soziale Entwicklung, Prävention, Intervention. Berlin, Heidelberg: Springer; 2013.

24. Taylor RM, Gibson F, Franck LS. The experience of living with a chronic illness during adolescence: A critical review of the literature. J Clin Nurs. 2008;17(23):3083-91.

25. Parsons HM, et al. Impact of cancer on work and education among adolescent and young adult cancer survivors. J Clin Oncol. 2012;30(19):2393-400.

26. Main DS, et al. Aqualitative study of work and work return in cancer survivors. Psychooncology. 2005;14(11):992-1004.

27. Bullinger M, Kirchberger I. SF-36 Fragebogen zum Gesundheitszustand. Göttingen: Hogrefe; 1998.

28. WareJJr., Kosinski M, Keller SD. A 12-item short-form health survey: Construction of scales and preliminary tests of reliability and validity. Med Care. 1996;34(3):220-33.

29. Dillmann U, et al. Assessing disability in chronic pain patients. Schmerz. 1994;8(2):100-10.

30. Ginzberg E, et al. Occupational choice. In: Athanasou J, Van Esbroeck R, editors. International handbook of career guidance. NewYork: Springer; 2008.

31. Jepsen DA, Dilley JS. Vocational decision-making models: A review and comparative analysis. Rev Educ Res. 1974;44(3):331-49.

32. Vroom VH. Work and motivation. New York: Wiley; 1964.

33. von Elm E, et al. The Strengthening the Reporting of Observational Studies in Epidemiology (STROBE) Statement: guidelines for reporting observational studies. Int J Surg. 2014;12(12):1495-9.

34. Wiegele K, et al. Onkologische Erkrankungen im Kindesalter: Einflüsse auf die Berufswahl. 52 Jahrestagung der Österreichischen Gesellschaft für Kinder- und Jugendheilkunde (ÖGKJ); SEP 17 - 19, 2014; Vienna. 2014.

35. Gianakos I. Patterns of career choice and career decisionmaking self-efficacy. JVocat Behav. 1999;54(2):244-58.

36. Khan RB, et al. Neurologic morbidity and quality of life in survivors of childhood acute lymphoblastic leukemia: A prospective cross-sectional study. J Cancer Surviv. 2014;8(4):688-96.

37. Krull KR, et al. Adolescent behavior and adult health status in childhood cancer survivors. J Cancer Surviv. 2010;4(3):210-7.

38. Naughton MJ, Weaver KE. Physical and mental health among cancer survivors: Considerations for long-term care and quality oflife. NCMed J.2014;75(4):283-6.

39. Oancea SC, et al. Emotional distress among adult survivors of childhood cancer. J Cancer Surviv. 2014;8(2):293-303.

40. Pleyer C. Onkologie: Verstehen-wissen-pflegen. München, Jena: Urban \& Fischer; 2012. ISBN 978-3437273452. 